\title{
Environmental Burden Analyzer for Machine Tool Operations and Its Application
}

\author{
Hirohisa Narita \\ School of Health Sciences, Fujita Health University \\ Japan
}

\section{Introduction}

The manufacturing technologies have been evolving according to development of evaluation methods for quality, productivity and cost. In spite of the need for ecomanufacturing, the relationship between manufacturing technologies and environmental burdens has not been yet revealed. Machining is a major manufacturing activity, hence an analyzer developed evables to estimate the environmental burden due to machine tool operations. The machine tool operations has a big potential influence regarding envirnmental burden, and then the envirnmental burden analyzer is developed based on LCA (life cycle assessment) (SETAC, 1999).

Some environmental burden analyses for machine tool operations have the problem which isn't suited to evaluating cutting conditions in detail (Shimoda, 2000, Touma et al., 2003). For example, the conventional methods can evaluate only the difference among dry, wet and MQL (minimal quantities of lubricant) machining operations, but not the difference among depth of cuts, feed rate, spindle speed and tool path pattern. Furthermore, if removal volume and material type are same, the environmental burden becomes same. That is to say accurate environmental burden can't be provided for deciding the cutting conditions.

One research proposed manufacturing planning with consideration of multi-endpoint environmental effects, but any concrete evaluation ways of machining operation haven't been presented (Hara et al., 2005, Sheng et al., 1998). The other researches discussed environmental burden based on energy consumption(Diaz et al., 2010), but did not cmprehensicely evaluate the related environmental burden. I should thus be able to develop the envirnmental burden analyzer for machine tool operations to realize sustainable manufacturing (OECD, 2009). I also proposed a decision method of cutting conditions to achieve minimum environmental burden with using the analyzer developed. The analyzer will enable to accelerate the development of environmental technologies and eco-industries. A calculation algorithm of environmental burden, a system overview and some application example are described in this paper.

\section{Life Cycle Assessment}

Generally, LCA is a very useful methodology for estimating the environmental burden of a product or service associated with all stages: row-material production, manufacture, 
transportation, use, repair and maintenance, and disposal or recycling. LCA has four processes: goal and scope definition, inventory analysis, impact assessment, and interpretation, and then realizes holistic assessment of environmental aspect and helps a more informed decision regarding product design modifications and business strategies.

This paper proposes an application technique of LCA to machining processes. For this purpose, machining process and machine tool models in computer environment is constructed and an environmental burden analyzer is developed. Cutting conditions achieving low environmental burden are also discussed by using the analyzer developed.

\section{System overview}

Figure 1 explains an overview of the environmental burden analyzer for machine tool operations. A workpiece, cutting tool models and an NC program are entered to the analyzer, all activities including a machine tool operation and a machining process are made an estimation. At that time, electric consumption of a machine tool peripheral devices and motors, cutting tool's wear, coolant quantity, lubricant quantity, metal chip quantity and other factors are calculated. Here, the other factors correspond to electric consumptions of air conditioning, light, AGV's transportation, products washing and etc. Using these calculated factors, emission intensity data and resource data, the environmental burden is obtained, when a part is machined. The emission intensity is the rate of an emission matter for an impact category. For example, quantity of carbon dioxide emitted per joule of energy produced for global warming. The emission intensity data is prepared according to an impact category such as global warming, acidification, toxicity to ecosystem, toxicity to human, eutrophication and nuclear radiation. The resource data also is a machine tool specification data, cutting tool parameters and physical parameters of the cutting force for the estimation of machining process. The cutting tool parameter corresponds to tool's diameter, helical angle, rake angle and number of tooth.

This analyzer can calculate the environmental burden in various cutting conditions, because a machining process is evaluated properly. This is a novel aspect of this research as compared with the conventional approach.

Generally, an impact category must be de determined and relevant emission factors of the impact category are selected for LCA. Global warming is determined as an impact category and carbon dioxide $\left(\mathrm{CO}_{2}\right)$, methane $\left(\mathrm{CH}_{4}\right)$ and dinitrogen monoxide $\left(\mathrm{N}_{2} \mathrm{O}\right)$ are selected as the it's relevant emission factors. Influences of halocarbon, and sulfur hexafluoride (SF6) on global warming are well known. However, these relevant emission factors are ignored, because their emission intensities have not been found according to my survey. All emissions are converted to equivalent $\mathrm{CO}_{2}$ emission by multiplying them by characterization factors, and then total equivalent $\mathrm{CO}_{2}$ emission is calculated as the environmental burden. The global warming potential (GWP) of 100-year impact (IPCC, 2007) is used as the characterization factors, as shown in Table 1.

\begin{tabular}{|c|c|c|c|}
\hline & $\mathrm{CO}_{2}$ & $\mathrm{CH}_{4}$ & $\mathrm{~N}_{2} \mathrm{O}$ \\
\hline $\begin{array}{l}\text { Global warming } \\
\text { potential (GWP) }\end{array}$ & 1 & 25 & 298 \\
\hline
\end{tabular}

Table 1. Characterization factors of global warming (IPCC, 2007) 


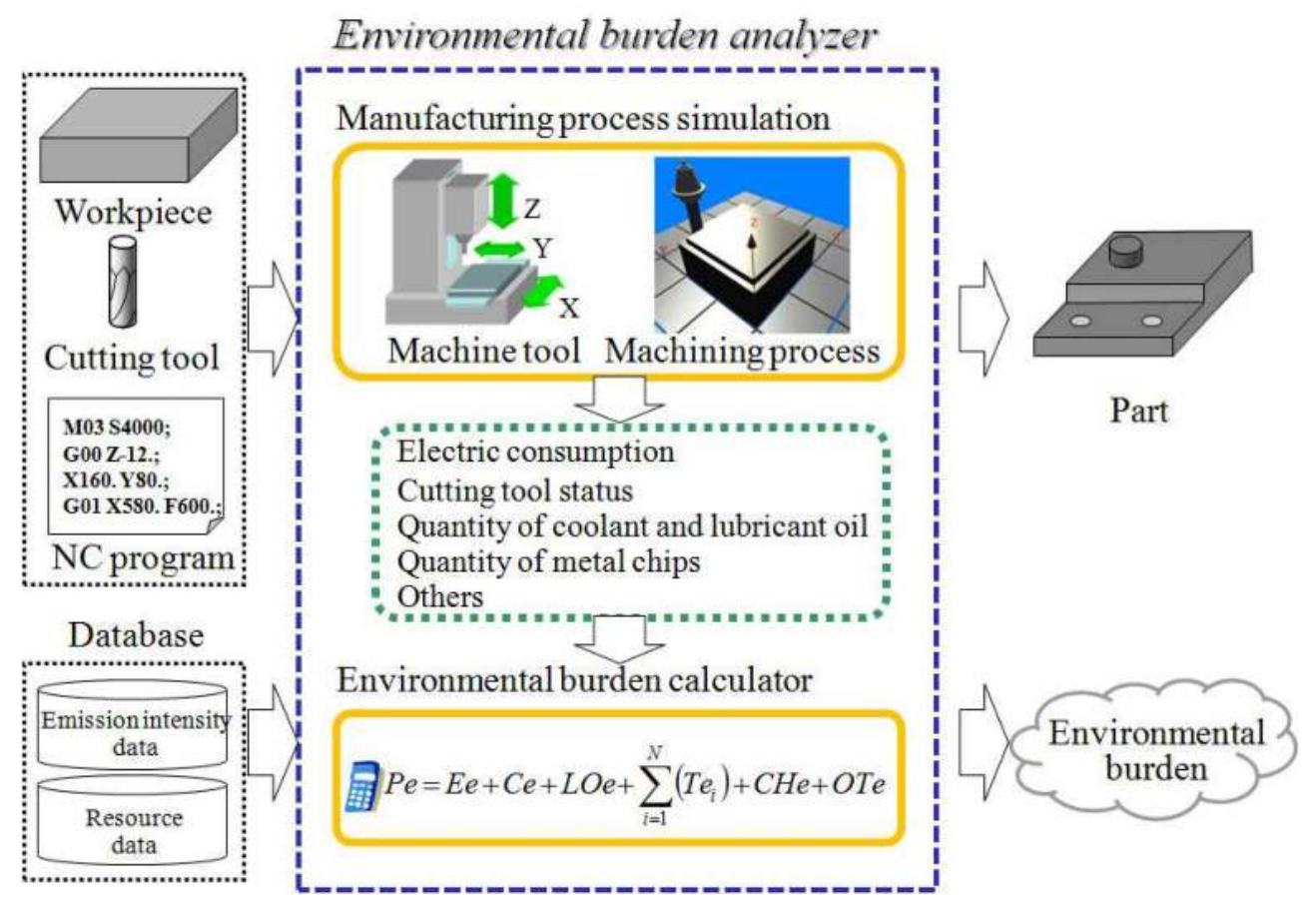

Fig. 1. An overview of the environmental burden analyzer for machine tool operations

\section{A calculation algorithm of environmental burden}

\subsection{Total environmental burden due to a machine tool}

Eq.(1) describes total environmental burden due to a machine tool operation, which is obtained from the electric consumption of the machine tool, the coolant, the lubricant oil, the cutting tool's wear, the metal chip and the other factors.

$$
\mathrm{Pe}=\mathrm{Ee}+\mathrm{Ce}+\mathrm{LO} e+\sum_{i=1}^{N}\left(\mathrm{Te}_{i}\right)+\mathrm{CHe}+\mathrm{OTe}
$$

$P e$ : Environmental burden of machining operation $\left[\mathrm{kg}-\mathrm{CO}_{2}\right]$

$E e$ : Environmental burden of machine tool component $\left[\mathrm{kg}-\mathrm{CO}_{2}\right]$

$\mathrm{Ce}$ : Environmental burden of coolant $\left[\mathrm{kg}-\mathrm{CO}_{2}\right]$

LOe: Environmental burden of lubricant oil $\left[\mathrm{kg}-\mathrm{CO}_{2}\right]$

$\mathrm{Te}$ : Environmental burden of cutting tool $\left[\mathrm{kg}-\mathrm{CO}_{2}\right]$

$\mathrm{CHe}$ : Environmental burden of metal chip $\left[\mathrm{kg}-\mathrm{CO}_{2}\right]$

$\mathrm{OTe}$ : Environmental burden of other factors $\left[\mathrm{kg}-\mathrm{CO}_{2}\right]$

$\mathrm{N}$ : Number of cutting tool used in an NC program

OTe isn't introduced in this paper. Calculation algorithms of these factors $(E e, C e, L O e, T e$ and $\mathrm{CHe}$ ) are introduced in detail as follows. 


\subsection{Electric consumption of machine tool (Ee)}

Ee means the environmental burden due to the electric consumption in an NC program. Figure 2 shows the electric consumption model of a machine tool, and the environmental burden due to the electric consumption of machine tool is described as follows.

$E e=k(S M E+S P E+S C E+C M E+C P E+T C E 1+T C E 2+A T C E+M G E+O A E+C O E+C U E+S B E)$

$k$ : $\mathrm{CO}_{2}$ emission intensity of electricity $\left[\mathrm{kg}-\mathrm{CO}_{2} / \mathrm{kWh}\right]$

$S M E$ : Electricity consumption of servo motors [kWh]

$S P E$ : Electricity consumption of a spindle motor [kWh]

NCE: Electricity consumption of an NC controller [kWh]

$S C E$ : Electricity consumption of a cooling system of spindle [kWh]

$C M E$ : Electricity consumption of a compressor [kWh]

$C P E$ : Electricity consumption of a coolant pump [kWh]

TCE1: Electricity consumption of a lift up chip conveyor [kWh]

TCE2: Electricity consumption of a chip conveyor in machine tool [kWh]

ATCE: Electricity consumption of an auto tool changer (ATC) [kWh]

$M G E$ : Electricity consumption of a tool magazine motor [kWh]

$O A E$ : Electricity consumption of an oil air compressor [kWh]

COE: Electricity consumption of an oil mist compressor [kWh]

CUE: Electricity consumption of a chip air blow compressor [kWh]

$S B E$ : Stand-by energy of a machine tool [kWh]

In Eq. (2), the electric consumption of peripheral devices such as an NC controller, a cooling system of spindle, a compressor, a coolant pump, a lift up chip conveyor, a chip conveyor in machine tool, an ATC, a tool magazine motor and stand-by energy are calculated by their running times. But CPE, TCE1, TCE2, COE and CHE may not be used according to a machine tool operation with or without coolant usage. We must survey through the

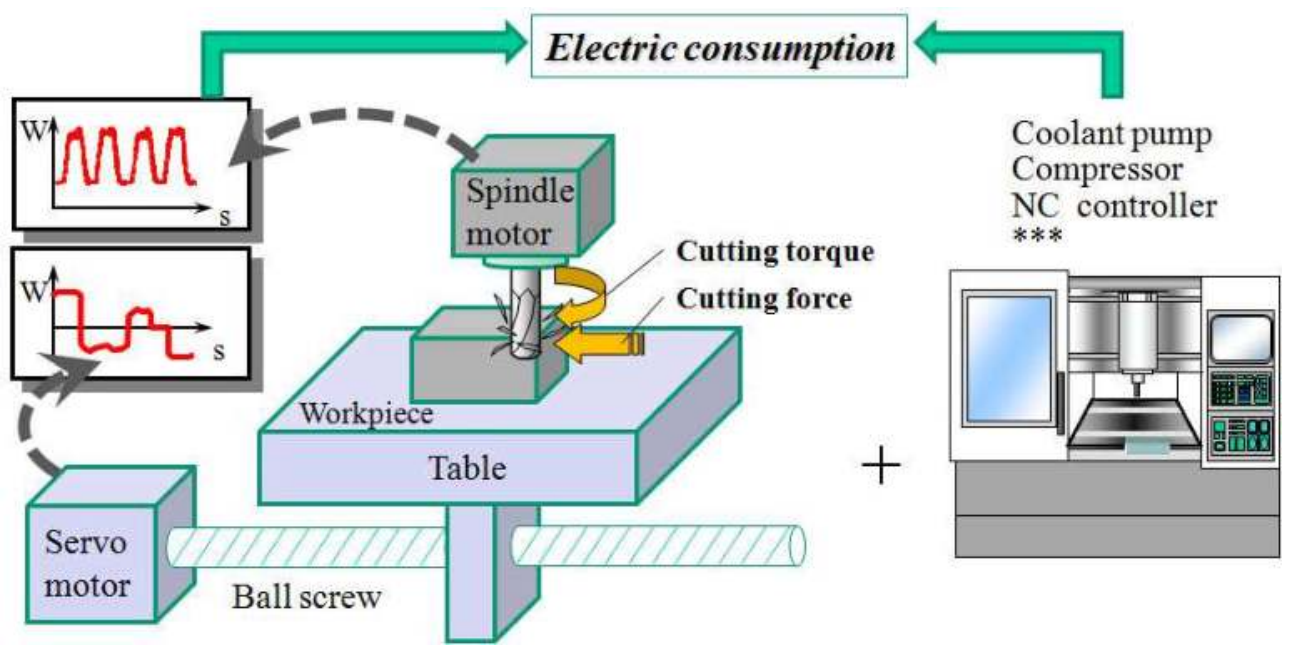

Fig. 2. Electric consumption model for machine tool 
machine tool specification previously whether or not to consider these electric consumptions. The electric consumption of the servo motors and spindle motor is also varied dynamically according to the machining process, hence new analysis model must be constructed.

The load torques of servo motors are calculated as follows.

$$
T_{\text {Lservo }}=T_{U}+T_{M}
$$

$T_{L \text { servo: }}$ load torque of servo motor $[\mathrm{N} \cdot \mathrm{m}]$

$T_{U}$ : axis friction torque $[\mathrm{N} \mathrm{m}]$

$T_{M}$ : application torque of ball screw $[\mathrm{N} \cdot \mathrm{m}]$

Here, $T_{U}$ is a torque due to rubber sealing and can't be obtained theoretically, thus its value is decided by an experiment. $T_{M}$ is calculated as follows.

$$
T_{M}=\frac{(\mu \cdot M \mp f) \cdot l \cdot \cos \theta \pm(M-f) \cdot l \cdot \sin \theta}{2 \pi \cdot \eta}
$$

$\mu$ : Friction coefficient of slide way

$\eta$ : Transmissibility of ball screw system

$l$ : Ball screw lead [m]

M: Moving part weight (table and workpiece) [N]

$f$ : Cutting force in an axis $[\mathrm{N}]$

$\theta$. Gradient angle from horizontal plane [rad]

This equation is reconstructed by a monitoring method for cutting force (Fujimura and Yasui, 1994) with normal and reverse rotations of the servo motor. $\theta$ is 0 in the $X$ - and $Y$ axes, and $\pi / 2$ in the $Z$-axis. The cutting force in an axis, $f$, and the load torque of the spindle motor, $T_{L}$ spindle, are calculated from the cutting force model. Virtual machining simulator I devloped (Narita et al., 2006) is applied for the purpose of estimating the aforementioned cutting force and cutting torque.

The calculated motor torque is converted to electric consumption as follows.

$$
P=\frac{2 \pi}{60} \times n \times T_{L} \times t
$$

$P$ : Electric consumption [Wh]

$T L$ : Load torque $\left(T_{L \text { servo }}\right.$ or $\left.T_{L \text { spindle }}\right)[\mathrm{N} \cdot \mathrm{m}]$

$n$ : Motor rotation speed [rpm]

$t$ : Time [hr]

The electric consumption of the compressors corresponding to CPE, TCE1, TCE2, COE and $\mathrm{CHE}$, is also varied according to a discharge pressure and the air dryer, hence the following equation is adapted for the estimation.

$$
E c=C E n+C F+A D F r+A D F a
$$

Ec: Electric consumption related to compressor $[\mathrm{kW}]$ 
$C E n$ : Electric motor power of main motor for compressor [kW]

$C F$ : Rated electric motor power of fan motor for compressor [kW]

$A D F r$ : Rated power of cooling machine of air-dryer [kW]

$A D F a$ : Rated power of cooling fan of air-dryer [kW]

\subsection{Coolant $(\mathrm{Ce})$}

$\mathrm{Ce}$ means the environmental burden due to the coolant in an NC program. There are two types cutting fluid, hence two equations are proposed for $\mathrm{Ce}$. Regarding water-miscible cutting fluid, coolant is generally used to enhance machining performance and circulated in a machine tool by coolant pump until coolant is made replacement. During this period, some coolants are eliminated by adhesion to metal chips, hence coolant is supplied for this compensation. The reduction of the dilution fluid (water) due to vapor has to be also considered to estimate total coolant. Here, the following equation is adopted to calculate the environmental burden due to the coolant.

$$
C e=\frac{C U T}{C L} \times\{(C P e+C D e) \times(C C+A C)+W A e \times(W A Q+A W A Q)\}
$$

CUT: coolant usage time in an NC program [s]

$C L$ : mean interval of coolant update [s]

$\mathrm{CPe}$ : environmental burden of cutting fluid production $\left[\mathrm{kg}-\mathrm{CO}_{2} / \mathrm{L}\right]$

$\mathrm{CDe}$ : environmental burden of cutting fluid disposal $\left[\mathrm{kg}-\mathrm{CO}_{2} / \mathrm{L}\right]$

CC: initial coolant quantity [L]

$A C$ : additional supplement quantity of coolant [L]

WAe: environmental burden of water distribution $\left[\mathrm{kg}-\mathrm{CO}_{2} / \mathrm{L}\right]$

WAQ: initial quantity of water [L]

$A W A Q$ : additional supplement quantity of water [L]

\subsection{Lubricant oil (LOe)}

LOe means the environmental burden due to the lubricant oil in an NC program. The lubricant oil is used for two main types. One is for a spindle, another is for a slide way. Here, Minute amounts of oil are supplied by a pump to the spindle and the slide way within a specific interval. Grease as a lubricant is not introduced here, but the same equations can be applied to calculate the environmental burden due to grease. The environmental burden due to the lubricant oil is calculated as follows.

$$
L O e=\frac{S R T}{S I} \times S V \times(S P e+S D e)+\frac{L U T}{L I} \times L V \times(L P e+L D e)
$$

$S R T$ : Spindle runtime in an NC program [s]

$S V$ : Discharge rate of spindle lubricant oil [L]

SI: Mean interval between discharges [s]

$\mathrm{SPe}$ : Environmental burden of spindle lubricant oil production $\left[\mathrm{kg}-\mathrm{CO}_{2} / \mathrm{L}\right]$

$S D e$ : Environmental burden of spindle lubricant oil disposal $\left[\mathrm{kg}-\mathrm{CO}_{2} / \mathrm{L}\right]$

LUT: Slide way runtime in an NC program [s]

LI: Mean interval between supplies [s] 
$L V$ : Lubricant oil quantity supplied to slide way [L]

LPe: Environmental burden of slide way lubricant oil production $\left[\mathrm{kg}-\mathrm{CO}_{2} / \mathrm{L}\right]$

$L D e$ : Environmental burden of slide way lubricant oil disposal $\left[\mathrm{kg}-\mathrm{CO}_{2} / \mathrm{L}\right]$

\subsection{Cutting tool (Te)}

$\mathrm{Te}$ means the environmental burden due to the cutting tools in an NC program. All cutting tools are managed by tool life, hence a tool life is compared with machining time to calculate the environmental burden in a machining. Cutting tools, especially for solid end mills, are often renewed by regrinding. The environmental burden due to the cutting tool is calculated as follows by considering the aforementioned processes.

$$
T e=\frac{M T}{\sum_{j=1}^{R N+1} T L_{j}} \times((T P e+T D e) \times T W+R N \times R G e)
$$

MT: Machining time [s]

TL: Tool life [s]

TPe: Environmental burden of cutting tool production $\left[\mathrm{kg}-\mathrm{CO}_{2} / \mathrm{kg}\right]$

TDe: Environmental burden of cutting tool disposal $\left[\mathrm{kg}-\mathrm{CO}_{2} / \mathrm{kg}\right]$

TW: Tool weight $[\mathrm{kg}]$

$R G N$ : Total number of regrinding processes

$R G e$ : Environmental burden of regrinding $\left[\mathrm{kg}-\mathrm{CO}_{2}\right]$

\subsection{Metal Chips (CHe)}

$\mathrm{CHe}$ means the environmental burden due to the metal chips in an NC program.

Metal chip recycling, in which a chip compactor, a chip crusher, a centrifugal separator and an arc furnace are used, generates an environmental burden. In this research, the environmental burden is calculated with considering chip weight as follows.

$$
\mathrm{CHe}=(W P V-P V) \times M D \times W D e
$$

WPV: Workpiece volume $\left[\mathrm{cm}^{3}\right]$

$P V$ : Product volume $\left[\mathrm{cm}^{3}\right]$

$M D$ : Material density of workpiece $\left[\mathrm{kg} / \mathrm{cm}^{3}\right]$

WDe: Environmental burden of metal chip processing $\left[\mathrm{kg}-\mathrm{CO}_{2} / \mathrm{kg}\right]$

\subsection{Output example of the developed analyzer}

Figure 3 shows an output example of the developed analyzer. The left part shows the machining process instructed by an NC program and estimate cutting force, cutting torque, electric consumption, quantity of cutting oil, quantity of lubricant oil, usage time of cutting tool and metal chip volume. The right part also shows the environmental burden calculated by the aforementioned algorithm. This analyzer can evaluate various environmental burdens by inputting the emission intensities related to the impact categories. 


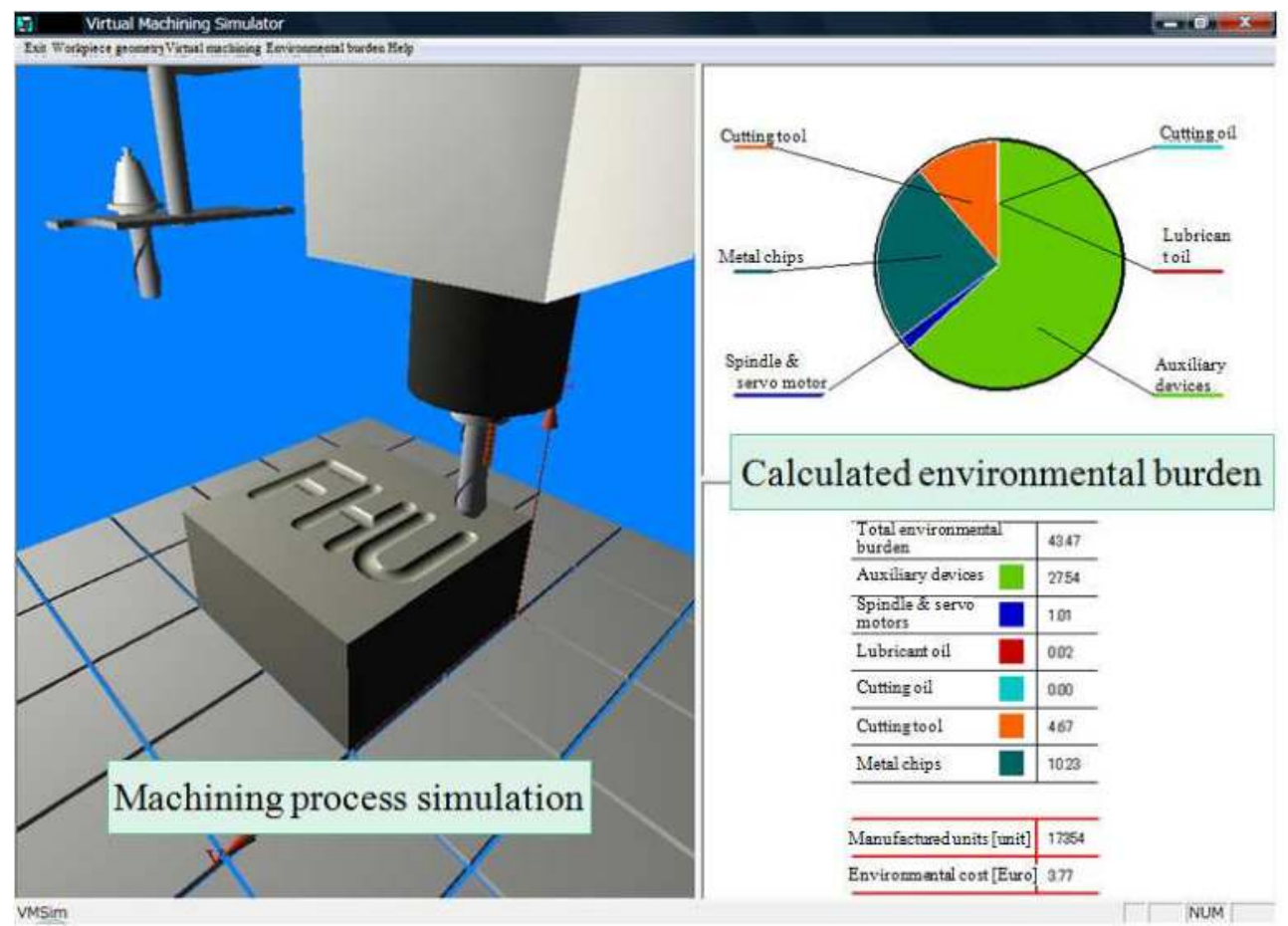

Fig. 3. An output example of the developed analyzer

\section{Case study}

\subsection{Comparison of cutting conditions}

For this case study, a machine tool is a vertical machining center (MB-46VA, OKUMA Corp.), a cutting tool is carbide-square end mill with $6 \mathrm{~mm}$-diamater and 2-flulte, and a workpiece is a medium carbon steel (S50C) and a compressor is a screw compressors (SCD110JC, Anest Iwata Corp.).

The parameters to calculate the electric consumption of the servo motor of the machine tool and the electric powers of the peripheral devices of the machine tool are summarized in tables 3 and 4, respectively. These values have been measured and obtained from an instruction manual of the machine tool. The friction torque of servo motors also has been determined by experiment in advance. Table 4 shows the other parameters regarding a machine tool operation.

Table 5 shows the $\mathrm{CO}_{2}$ emission intensities required to calculate the environmental burden of machining operations. These values were cited from some reports, such as environmental reports, technical reports, homepages and industrial tables (Tokyo Electric Power Company, (2005, Bureau of Waterworks Tokyo Metropolitan Government, 2003, Nansai et al., 2002, Osaka prefecture, 2003, 2005, Mizukami, 2002). 


\begin{tabular}{|c|c|}
\hline Table part weight $[\mathrm{kg}]$ & X: 903, Y:230, Z: 512 \\
\hline Friction coefficient of slide way & All axes: 0.01 (linear guide) \\
\hline Ball screw lead [mm] & X, Y: 20, Z: 16 \\
\hline Transmissibility of ball screw system & 0.95 \\
\hline
\end{tabular}

Table 2. Parameters to calculate the electric consumption of the servo motor

\begin{tabular}{|c|c|}
\hline NC controller [kW] & 0.16 \\
\hline Cooling system of spindle [kW] & 0.45 \\
\hline Compressor [kW] & 1 \\
\hline Coolant pump [kW] & 0.25 \\
\hline Lift up chip conveyor[kW] & 0.1 \\
\hline Chip conveyor in machine tool [kW] & 0.6 \\
\hline ATC [Wh] & 0.08 \\
\hline Tool magazine [Wh] (1 round) & 0.087 \\
\hline Vampire (stand-by) energy [kW] & 0.64 \\
\hline
\end{tabular}

Table 3. Electric consumptions and powers of machine tool

\begin{tabular}{|c|c|}
\hline Initial cutting fluid quantity [L] & 8.75 \\
\hline Additional supplement of cutting fluid [L] & 4.3 \\
\hline Initial dilution fluid quantity [L] & 175 \\
\hline Additional supplement of dilution fluid [L] & 82.25 \\
\hline Mean interval between replacements of coolant in pump [Month] & 5 \\
\hline Discharge rate of spindle lubricant oil [mL] & 0.03 \\
\hline Mean interval between discharges for spindle lubrication [s] & 480 \\
\hline Lubricant oil supplied to slide way[mL] & 228 \\
\hline Mean interval between supplies [hour] & 2000 \\
\hline Tool life [s] & 5400 \\
\hline Total number of regrinding processes & 2 \\
\hline Material density of cutting tool [g/cm ${ }^{3}$ ] & 11.9 \\
\hline Material density of workpiece [g/cm ${ }^{3}$ ] & 7.1 \\
\hline Coolant tank capacity of machine tool [L] & 175 \\
\hline
\end{tabular}

Table 4. Other parameters for machine tool operation

\begin{tabular}{|c|c|}
\hline Electricity $\left[\mathrm{kg}-\mathrm{CO}_{2} / \mathrm{kWh}\right]$ & 0.381 \\
\hline Cutting fluid production $\left[\mathrm{kg}-\mathrm{CO}_{2} / \mathrm{L}\right]$ & 0.978 \\
\hline Cutting fluid disposal $\left[\mathrm{kg}-\mathrm{CO}_{2} / \mathrm{L}\right]$ & 0.0029 \\
\hline Dilution liquid (water) $\left[\mathrm{kg}-\mathrm{CO}_{2} / \mathrm{L}\right]$ & 0.189 \\
\hline Spindle and slide way lubricant oil production $\left[\mathrm{kg}-\mathrm{CO}_{2} / \mathrm{L}\right]$ & 0.469 \\
\hline Spindle and slide way lubricant oil disposal $\left[\mathrm{kg}-\mathrm{CO}_{2} / \mathrm{L}\right]$ & 0.0029 \\
\hline Cutting tool production $\left[\mathrm{kg}-\mathrm{CO}_{2} / \mathrm{kg}\right]$ & 33.7 \\
\hline Cutting tool disposal $\left[\mathrm{kg}-\mathrm{CO}_{2} / \mathrm{kg}\right]$ & 0.0135 \\
\hline Regrinding $\left[\mathrm{kg}-\mathrm{CO}_{2} /\right.$ number] & 0.0184 \\
\hline Metal chip processing $\left[\mathrm{kg}-\mathrm{CO}_{2} / \mathrm{kg}\right]$ & 0.322 \\
\hline
\end{tabular}

Table 5. Equivalent $\mathrm{CO}_{2}$ emission intensities 
Figure 4 shows a part shape and a tool path pattern used for an example and table 6 shows the cutting conditions of NC program. Three cutting condition: Program 1, Program 1 with coolant (water miscible type) and Program 2 are evaluated. Here, a feed rate of immersion to workpiece is $100 \mathrm{~mm} / \mathrm{min}$ and the tool life is assumed to be increased to 1.5 times of the original one due to the coolant effect.
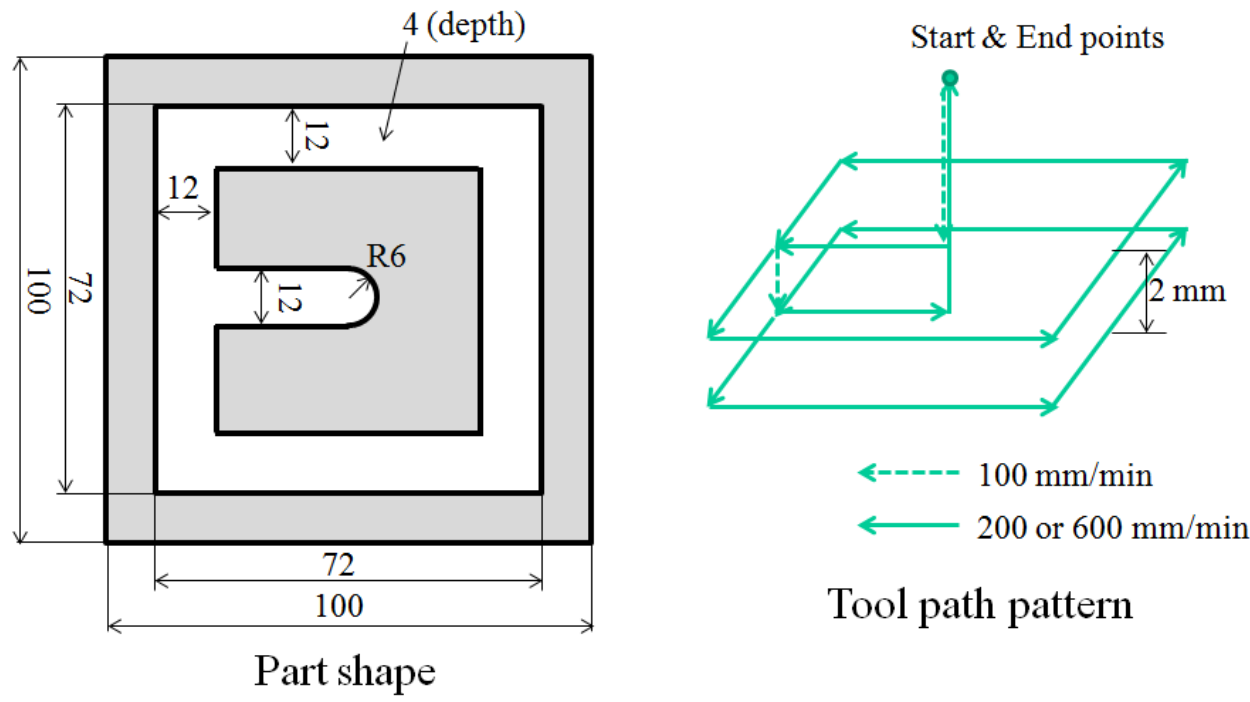

Tool path pattern

Fig. 4. Part shape and tool path pattern

\begin{tabular}{c|c|c}
\hline & Program 1 & Program 2 \\
\hline Spindle speed [rpm] & 2500 & 7500 \\
\hline Feed rate [mm/min] & 200 & 600 \\
\hline
\end{tabular}

Table 6. Cutting conditions of NC programs

Figure 5 shows calculated results of three cutting conditions. Program 2 is best in three cutting conditions, because the machining time is very short. The environmental burden due to the cutting tool is reduced by the coolant effect, but the one due to electric consumption of peripheral devices are increased by the usage of coolant pump. As a matter of course, the one of coolant is increased but small. It is found that main reason of the increase of environmental burden due to the coolant usage is the one due to the peripheral devices as shown in this figure. As shown in this case study, the developed analyzer can evaluate various cutting conditions in details.

\subsection{Determination method to realize low environmental burden}

The environmental burden due to the peripheral devices must be reduced in order to reduce total environmental burden as shown in Fig.5. The one due to the peripheral devices is proportional to time, hence high speed milling might be effect. 


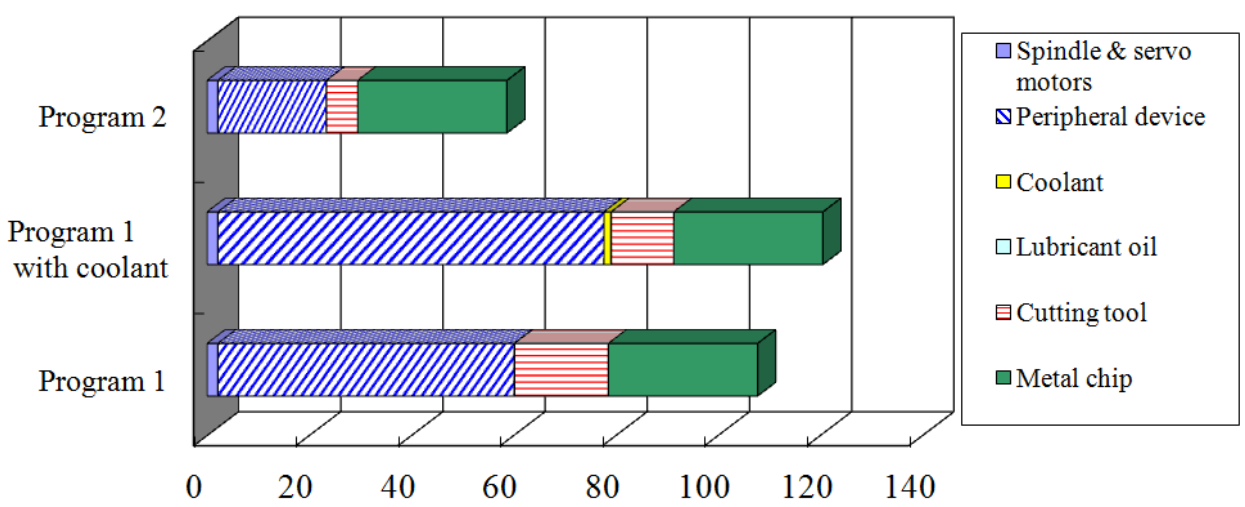

Fig. 5. Comparison of various cutting conditions

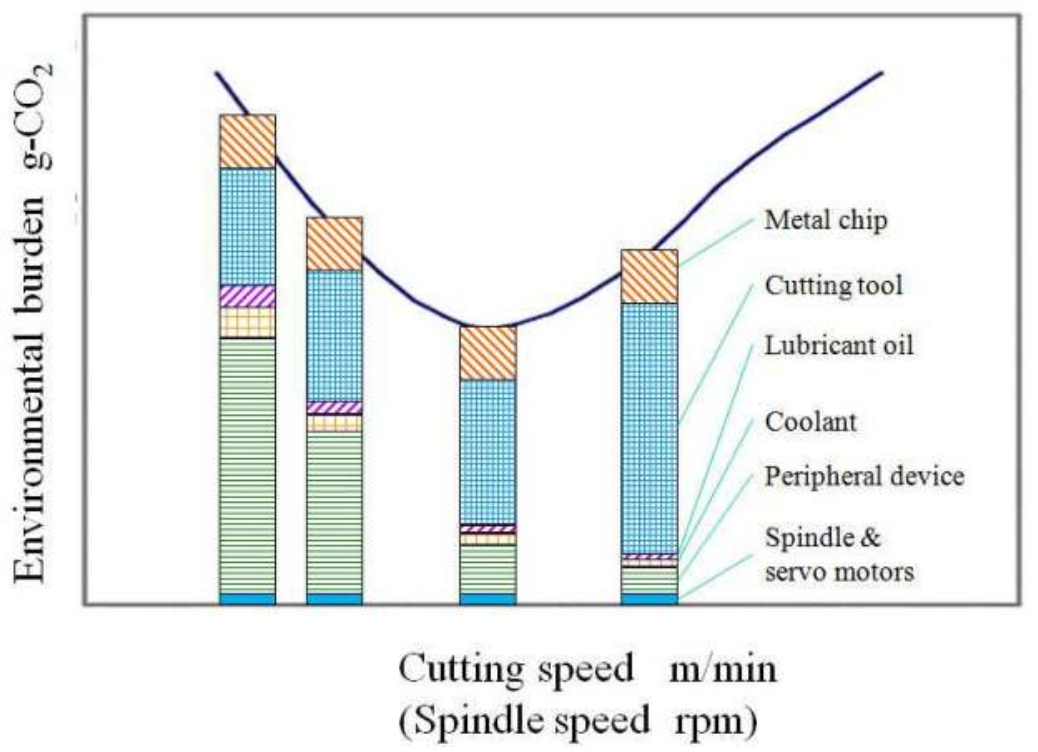

Fig. 6. Tendency due to high speed milling

Here, the relationship between the environmental burden and the cutting speed (spindle speed) is discussed when a feed per tooth, a radial depth and an axial depth of cuts are constant. Figure 6 shows a tendency due to the high speed milling. A tool wear becomes extremely large [Jiang, 2011] and a tool life will shorten in high speed millings, hence the environmental burden due to the cutting tool will increase. But the one due to the electric consumption, coolant and lubricant oil is proportional to time. That is to say there is a tradeoff relation between the one due to the cutting tool and the one due to the electric consumption, coolant, lubricant oil. However the one due to the spindle and servo motors is very small (it is constant when the feed per tooth is constant), and the one due to the metal chip is constant, and then these environmental burdens are ignored for discussing. As 
shown in fig.6, there is a cutting condition to realize the minimum environmental burden. Hence, an optimum cutting speed (spindle speed) can be obtained automatically by calculating an approximate equation with using least-square method and exploring the cutting conditions achieving the minimum environmental burden with using iterative calculation. An optimum cutting speed (spindle speed) is attempted to be calculated as an example by embedding the aforementioned functions to the analyzer. A parabolic equation is applied for the approximate equation in this research.

A real tool wear data (Anzai, 2003) is used in order to confirm the tendency depicted in Fig.6. For this case study, cutting tool is a ball end mill with R10 and 2-flute, and workpiece is PX5. Cutting speed is varied from 50 to $550 \mathrm{~m} / \mathrm{min}$, the axial depth is $0.5 \mathrm{~mm}$, the radial depth is $0.8 \mathrm{~mm}$, the feed per tooth is $0.15 \mathrm{~mm} /$ tooth and the cutting length is $56.25 \mathrm{~m}$. The coolant is also used for this cutting. Figure 7 describes the relation of tool wears according to cutting speed. Here, a flank wear is used to distinguish its tool life and then the threshold of maximum tool wear is assumed to be $0.8 \mathrm{~mm}$, and the tool life in time domain is obtained.

Figure 8 shows a relation of equivalent $\mathrm{CO}_{2}$ emission according to the cutting speeds. The approximate equation is obtained regarding the plotted data as follows.

$$
y=3.38 \times 10^{-2} x^{2}-27.0 x+6.02 \times 10^{3}
$$

Where, $y$ means equivalent $\mathrm{CO}_{2}$ emission and $x$ means cutting speed. The minimum cutting speed is obtained by the iterative calculation and becomes $398.9 \mathrm{~m} / \mathrm{min}$ (about $12702 \mathrm{rpm}$ ).

A research introduces an importance about the decision of an optimum cutting condition achieving low environmental burden with using virtual reality technology before a real machining operation (Shao, 2010) based on my previous research (Narita, 2009), but any concrete ways to decide the optimum cutting condition from the view point of the environmental burden haven't been proposed so far. This is the first proposition how to decide the optimum cutting conditon achieving low environmental burden as show in this example. I believe the feasibility of the environmental burden analyzer can be described in this paper.

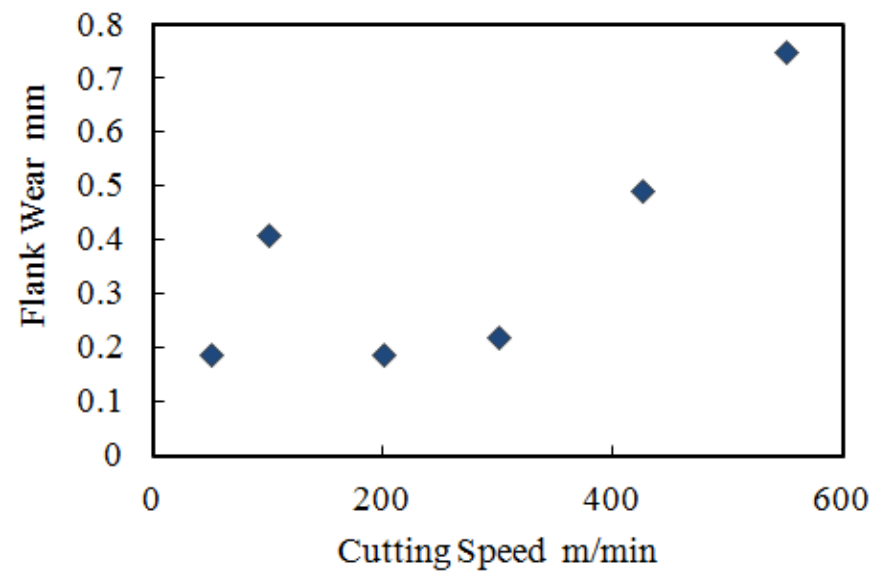

Fig. 7. Tool wears according to cutting speed (Anzai, 2003) 


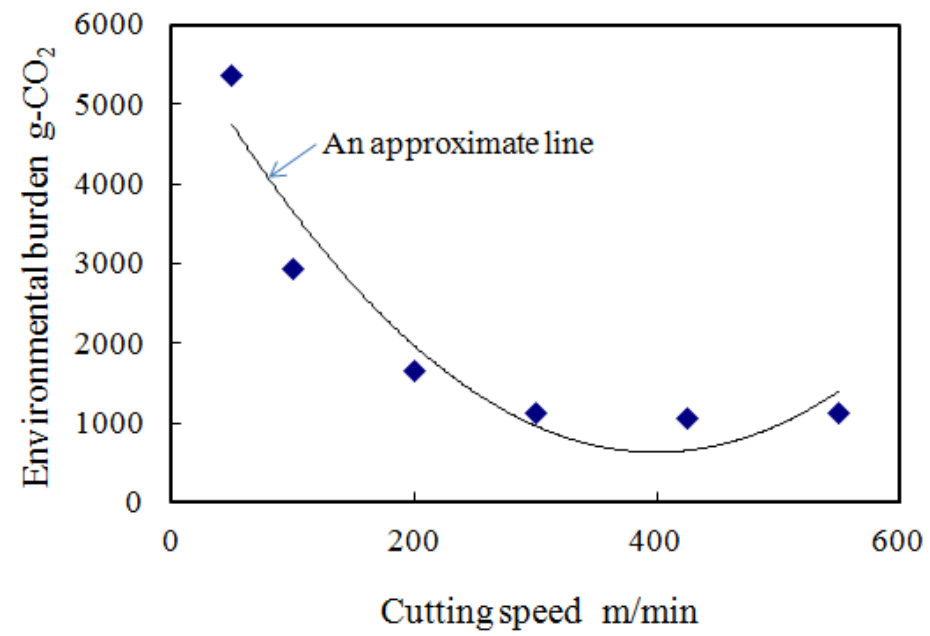

Fig. 8. Environmental burden vs. cutting speed

\section{Conclusion}

Conclusions are summarized as follows:

1. A algorithm to calculate environmental burden due to machine tool operations was proposed and the environmental burden analyzer for machine tool operations was developed.

2. A decision method of cutting conditions to achieve minimum environmental burden with using the developed analyzer was also proposed.

3. The feasibility of the environmental burden analyzer and the decision method of cutting conditions to achieve minimum environmental burden were demonstrated through examples.

\section{Acknowledgment}

I would like to express my sincere appreciation to the stuff of OKUMA Corp. for thoughtful support.

\section{References}

Anzai, M., The Cutting Characteristic of Mold Steel Under The High-Speed Milling Condition, Nachi Technical Report, Vol. 11 A1, 2006 (in Japanese).

Bureau of Waterworks Tokyo Metropolitan Government, (2003), Environmental report of Tokyo waterworks 2002(in Japanese).

Diaz, N., Choi, S., Helu, M., Chen, Y., Jayanathan, S., Yasui, Y., Kong, D., Pavanaskar, S. and Dornfeld, D., , (2010), Machine Tool Design and Operation Strategies for Green Manufacturing, Proceedings of 4th CIRP International Conference on High Performance Cutting , Gifu, Japan, pp.271-276. 
Fujimura, Y., Yasui, T. , (1994), Machine tool and manufacturing system, KYORITSU SHUPPAN Co. Ltd., (in Japanese).

Hara, Y., Tanaka, T. and Saito, Y. , (2005), Evaluation Method of the Power Consumption for Machine Tool, Proceeding of the 2005 JSPE Autumn Annual Conference (in Japanese) , Kyoto, Japan, pp.744-745.

IPCC Fourth Assessment Report (AR4) , (2007), Changes in Atmospheric Constituents and in Radiative Forcing.

Jiang, B., Qi, C., Xia, D., Cao, S., and Chen B. , (2011), Dynamics Characteristic of Cutter Wear in High Speed Milling Hardened Steel, Advanced Science Letters Vol. 4, 3103-3107

Mizukami, H., Yamaguchi, R., Nakayama, T., Maki, T., , (2002), Off-gas Treatment Technology of ECOARC, NKK Technical Report (in Japanese), No.176, pp.1-5.

Nansai, K., Moriguchi, Y. and Tohno, S. , (2002), Embodied Energy and Emission Intensity Data for Japan Using Input-Output Tables (3EID)-Inventory Data for LCA-, Center for Global Environment Research, National Institute of Environmental Studies, Japan.

Narita, H., Chen, L.Y., Fujimoto, H., Shirase, K. and Arai, E. , (2006), Trial-Less Machining Using Virtual Machining Simulator for Ball End Mill Operation, International Journal of the Japan Society of Mechanical Engineers, Series C, Vol.49, No.1, pp. 50-55.

Narita, H. and Fujimoto, H., Analysis of Environmental Impact Due to Machine Tool Operation, International Journal of Automation Technology, Vol.3, No.1, pp.49-55, 2009.

Organisation for Economic Co-operation and Development (OECD), (2009), Sustainable Manufacturing and Eco-innovation: Towards a Green Economy, OECD June 2009 Policy Brief.

Osaka prefecture, (2003), guideline index of waste material incinerator in Osaka prefecture, Osaka prefectural announcement No.618 (in Japanese).

Osaka prefecture, (2005), Osaka prefectural statistical yearbook 2004 (in Japanese).

SETAC, (1993), Guidelines for Life-Cycle Assessment: A Code of Practice.

Shao, G., Kibira, D. and Lyons, K., (2010), A Virtual Machining Model For Sustainability Analysis, Proceedings of ASME 2010 International Design Engineering Technical Conference \& Computers and Information in Engineering Conference, DETC2010-28743, August 15-18, Montreal, Quebec, Canada.

Sheng, P., Bennet, D., Thurwachter, S., / B.F. von Turkovich, (1998), Environmental-Based Systems Planning for Machining, Annals of the CIRP, Vol.47/1, p.409-414.

Shimoda, M. , (2000), LCA case of machine tool, Symposium of 2002 Japan Society for Precision Engineering Spring Annual Meeting "Leading-Edge Trend of Environmental Impact Evaluation for Inverse Type Design and Manufacturing", Nagoya, Japan, p. 37-41, (in Japanese).

Tokyo Electric Power Company, (2005), The Earth, People \& Energy TEPCO Sustainability Report 2004

Touma, S., Ohmori, S., Kokubo, K., Tateno, M. , (2003), Evaluation of Environmental Burden in Eco-friendly Machining Method using Life Cycle Assessment Method Estimation of Carbon Dioxide Emission in Eco-friendly Turing Method- Journal of the Japan Society for Precision Engineering, (in Japanese), Vol.69, No.6, p.825-830. 


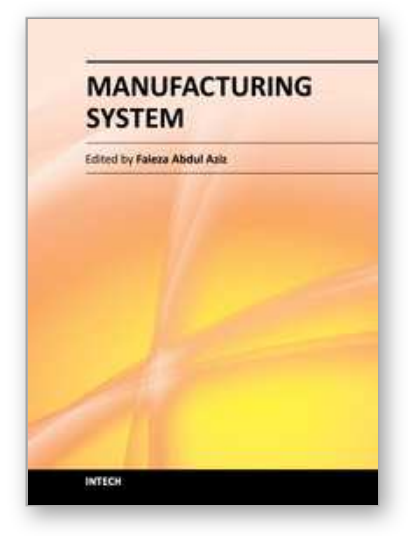

\author{
Manufacturing System \\ Edited by Dr. Faieza Abdul Aziz
}

ISBN 978-953-51-0530-5

Hard cover, 448 pages

Publisher InTech

Published online 16, May, 2012

Published in print edition May, 2012

This book attempts to bring together selected recent advances, tools, application and new ideas in manufacturing systems. Manufacturing system comprise of equipment, products, people, information, control and support functions for the competitive development to satisfy market needs. It provides a comprehensive collection of papers on the latest fundamental and applied industrial research. The book will be of great interest to those involved in manufacturing engineering, systems and management and those involved in manufacturing research.

\title{
How to reference
}

In order to correctly reference this scholarly work, feel free to copy and paste the following:

Hirohisa Narita (2012). Environmental Burden Analyzer for Machine Tool Operations and Its Application, Manufacturing System, Dr. Faieza Abdul Aziz (Ed.), ISBN: 978-953-51-0530-5, InTech, Available from: http://www.intechopen.com/books/manufacturing-system/environmental-burden-analyzer-for-machine-tooloperations-and-its-application

\section{INTECH}

open science / open minds

\section{InTech Europe}

University Campus STeP Ri

Slavka Krautzeka 83/A

51000 Rijeka, Croatia

Phone: +385 (51) 770447

Fax: +385 (51) 686166

www.intechopen.com

\section{InTech China}

Unit 405, Office Block, Hotel Equatorial Shanghai

No.65, Yan An Road (West), Shanghai, 200040, China 中国上海市延安西路65号上海国际贵都大饭店办公楼 405 单元 Phone: +86-21-62489820

Fax: +86-21-62489821 
(C) 2012 The Author(s). Licensee IntechOpen. This is an open access article distributed under the terms of the Creative Commons Attribution 3.0 License, which permits unrestricted use, distribution, and reproduction in any medium, provided the original work is properly cited. 